\title{
Oilseed Rape Transformation by Electroporation: Effects of Nurse Culture on Transformation
}

\author{
Junko KoHno-Murase, Reiko Yu and Jun Imamura \\ Plantech Research Institute, 1000 Kamoshida-cho, Midori-ku, \\ Yokohama, Kanagawa 227, Japan
}

(Received February 5, 1994)

(Accepted July 1, 1994)

Transgenic Brassica napus plants have been obtained after electroporation of hypocotyl protoplasts. We have tested electroporation parameters based on transient expression of $\beta$-glucuronidase (GUS) gene in the protoplasts. The number of GUS positive cells 4 days after electroporation was affected by use of tobacco suspension cells as nurse culture as well as the amplitude of the electric pulse. The defined conditions for the electroporation was used for the stable transformation. To obtain transgenic plants, neomycin phosphotransferase II $(n p t$ II) or hygromycin phosphotransferase $(h p h)$ genes with a GUS gene were co-transformed. Five and six transgenic plants out of 140 kanamycin and 33 hygromycin resistant calli, respectively, were obtained. Presence of the $n p t$ II and $h p h$ genes in the plants was confirmed by PCR and Southern blot analysis of genomic DNA. GUS activity was detected in one plant out of three hygromycin resistant transgenic plants analyzed.

\section{Introduction}

Brassica napus is an oil seed plant and lipid and protein constitute $40 \%$ and $20 \%$ of the seed weight, respectively. Much effort has been devoted to improving the quality and quantity of the storage compounds in the seeds by conventional breeding ${ }^{11}$.

Recent progress of plant transformation provide a more direct approach to modify the economically important characteristics. In $B$. napus, successful production of genetic engineered plants such as herbicide resistant ${ }^{2)}$, modified fatty acid composition ${ }^{3)}$ and quality of storage proteins ${ }^{4)}$ have been reported.

As a number of transgenic plants developed through field testing, biosafety of selectable markers, $n p t$ II and $h p h$, become a subject of discussion. In terms of biosafety, once the transformant was selected in vitro, inactivation or elimination of the antibiotic resistance markers has been desired. Excision of a selectable marker gene from transgenic plants by the use of site specific recombination have been reported ${ }^{5}$.

In direct transformation the marker gene and the genes of interest on separate vectors were co -introduced and integrated in different locations on the chromosomes ${ }^{6}$. If one can obtain transgenic plants, it might be possible to select plants lacking the marker gene in the progeny sibling (Y. Kimura, personal communcation).

Compared to Agrobacterium-mediated transformation, however, electroporation-mediated gene transfer has been utilized less in $B$. napus except for the use in transient gene expression studies ${ }^{6-8)}$. In the work reported here, we optimized the conditions for electroporation and established a 
protocol to recover kanamycin or hygromycin resistant calli and transgenic plants.
Abbreviation
$\mathrm{PCR}=$ polymerase chain reaction
CaMV 35S=cauliflower mosaic virus 35S RNA
NOS $=$ nopalin synthase

\section{Materials and Methods}

\section{Protoplast isolation}

Seeds of $B$. napus cv. Westar were surface sterilized with $5 \%$ calcium hypochlorite solution for $25 \mathrm{~min}$. with continuous shaking and then rinsed several times with sterilized distilled water. The seeds were germinated on MS medium ${ }^{9)}$ containing $3 \%$ sucrose and $0.4 \%$ agarose in the dark at $25^{\circ} \mathrm{C}$.

Protoplasts were prepared from 7 day-old hypocotyls according to the method of Sakai and Imamura ${ }^{10)}$.

\section{Plasmid preparation}

Plasmid pBI221(Clontech)was used for both transient and stable transformation. Plasmid pCaMVneo $^{11)}$ contains the $n p t$ II gene linked to the CaMV 35S promoter and the NOS terminator. Plasmid pLAN101MHyg contains the $h p h$ gene linked to the CaMV 35S promoter and the NOS terminator. The $h p h$ gene was derived from plasmid $\mathrm{pDH} 25^{12)}$.

\section{Electroporation and protoplast culture}

Isolated hypocotyl protoplasts were resuspended in $0.5 \mathrm{~m} l$ of a buffer $(70 \mathrm{mM} \mathrm{KCl}, 5 \mathrm{mM} \mathrm{MgCl} 2$, 0. $4 \mathrm{M}$ mannitol, 0. 1\% MES, pH 5. 8) ${ }^{13)}$ at $6 \times 10^{5} \mathrm{cells} / \mathrm{m} l$ with plasmid DNA $(40 \mu \mathrm{g} / \mathrm{m} l)$ and carrier DNA $(40 \mu \mathrm{g} / \mathrm{ml})$. The carrier DNA was prepared by dissolving calf thymus DNA(Sigma) in 10 mM Tris-HCl, 1 mM EDTA, pH 8.0 and sterilized by passing twice through a disposable filter. After the protoplasts-DNA mixture was chilled on ice for $30 \mathrm{~min}$., they were transferred to a plastic cuvette and electroporated using a capacitor discharge system(X-cell 450, Promege). The length of pulse was constant at $7.5 \mathrm{msec}$. After electroporation, the protoplasts were placed on ice for 30 min., and then transferred to a plastic plate $(60 \mathrm{~mm}$ in diameter) containing $2.5 \mathrm{~m} l$ of KM8p with 0 . $4 \mathrm{M}$ glucose, $1 \mathrm{mg} / l 2,4-\mathrm{D}, 0.1 \mathrm{mg} / l \mathrm{NAA}$ and $0.4 \mathrm{mg} / l \mathrm{BAP}$. Rapidly growing $1 \mathrm{~m} l$ of tobacco supension cell(BY2) were transferred into a Millicell(Millipore), and the Millicell containing the tobacco supension cells was put into a plastic plate as nurse culture. After one week in culture, kanamycin or hygromycin B were added to the protoplast culture at the final concentration of 10 $\mu \mathrm{g} / \mathrm{m} l$ and $5 \mu \mathrm{g} / \mathrm{m} l$, respectively. At the same time $0.1 \mathrm{~m} l$ of KM8p medium containing $0.1 \mathrm{M}$ sucrose instead of $0.4 \mathrm{M}$ glucose was added to sustain further growth of the colonies. After three weeks in culture, the colonies were transferred with large bore pipette onto $\mathrm{CN}$ medium containing the selection reagent and the excess medium was removed thorughly by pasteur pipette. Three weeks later green calli were transferred to DN medium containing the antibiotics. To induce shoots the green calli on the selection medium were transferred successively to a series of media, K3, B5, MS with the antibiotics every 3 weeks. Regenerated green shoots were transferred to B5 medium containing $0.1 \mathrm{mg} / l$ BAP, $3 \%$ sucrose and $0.6 \%$ agarose without the antibiotics. The green calli without shoot formation were further incubated on MS medium for another three weeks. For shoot growth MS medium substituted with B5 vitamins was used.

\section{Histochemical assay for $\beta$-glucuronidase}

Transient GUS expression was evaluated by a 5 -bromo-4-chloro-3-indolylglucuronide (X-Gluc) histochemical assay ${ }^{14)}$. After 4 days in protoplast culture, the cells were sedimented by centrifuga- 
tion at $600 \mathrm{rpm}$ for $3 \mathrm{~min}$. and resuspended with histochemical GUS assay buffer ${ }^{15}$. After over night incubation at $30^{\circ} \mathrm{C}$, the number of blue stained cells was counted under a microscope.

\section{Southern blot analysis}

Total DNA was extracted from leaves of the regenerated plants according to Doyle et al. $(1990)^{15)}$. The DNA was double digested with Eco RI and BamHI, electrophoresed in a 0.8\% agarose and transferred to a nylon membrane(Amasham, Hybond-N). The membrane was hybridized with random-primed ${ }^{32} \mathrm{P}$-labeled full length of $h p h$ gene(Multiprime Labeling Kit, Amasham) following the manufacture's recommendations, and washed successively with $2 \times \mathrm{SSC}$, $0.5 \times \mathrm{SSC}$, and $0.1 \times \mathrm{SSC}$ solution at $65^{\circ} \mathrm{C}$ for $15 \mathrm{~min}$. each washing, then exposed to Kodak OMAT $-\mathrm{AR}$ film at $-80^{\circ} \mathrm{C}$ with intensifying screens for $16-20 \mathrm{~h}$.

\section{Results and Discussion}

\section{Transient expression}

Parameters that might affect the transient expression of GUS gene in $B$. napus protoplast were studied. The transient transformation frequency was scored as the number of blue stained cells by microscopy. The GUS positive cells were never observed in non-transformed cells nor in transformed cells without the GUS gene. An optimum number of the GUS positive cells was produced at a combination of $400 \mu \mathrm{F}, 600 \mathrm{Vcm}^{-1}$ (33 Joule) and $7.5 \mathrm{msec}$. pulse time(Table 1). Higher electric energy produced fewer GUS positive cells. Bergman and Glimelius reported increasing discharge potential to over $800 \mathrm{Vcm}^{-1}$ decreased the number of GUS positive cells while decreasing the number of viable protoplast ${ }^{8}$. It was shown that transformation frequencies were affected by ion concentrations of the electroporation buffer ${ }^{16}$. For B. napus electroporation, optimun concentrations of $\mathrm{MgCl}_{2}$ and $\mathrm{CaCl}_{2}$ in the buffer have been reported ${ }^{8)}$. The optimum concentration of $\mathrm{CaCl}_{2}$ was $4 \mathrm{mM}$ and no GUS positive cells were observed in the buffer that contained $12 \mathrm{mM} \mathrm{CaCl}_{2}$.

Table 1. Number of GUS positive cells produced by electroporation with or without nurse culture.

\begin{tabular}{cclrr}
\hline \multirow{2}{*}{$\mu \mathrm{F}$} & \multirow{2}{*}{$\mathrm{V} \mathrm{cm}^{-1}$} & \multirow{2}{*}{ Joule } & \multicolumn{2}{c}{ No. of blue stained cells*2 } \\
\cline { 4 - 5 } & & & + & ${ }^{* 3}$ \\
\hline 400 & 600 & $(33)^{* 1}$ & $101(3.4)$ & $22(0.7)$ \\
200 & 1000 & $(46)$ & $55(1.8)$ & $15(0.5)$ \\
200 & 1250 & $(72)$ & $22(0.7)$ & $2(0.07)$ \\
400 & 1000 & $(92)$ & $12(0.4)$ & $7(0.2)$ \\
\hline
\end{tabular}

${ }^{* 1}$ Numbers in brackets are the caluculated energy of each electroporation treatment. The length of pulse was constant at $7.5 \mathrm{msec}$ in all treatments.

Joule $=\frac{\mu \mathrm{F} \times(\mathrm{V} / \mathrm{cm})^{2}}{2 \times 10^{6}} \times \mathrm{T}$

$\mathrm{T}$ : Constant value depended on the value of capacitance. It was 0 . 46 at $400 \mu \mathrm{F}$ and 0.71 at $200 \mu \mathrm{F}$.

*2 Number of blue stained calli per $3 \times 10^{5}$ electroporated protoplasts were calculated after 4 days in culture. Numbers in brackets are transient transformation frequencies $\left(\times 10^{-4}\right)$. Transient transformation frequency was caluculated as the number of GUS positive cells divided by the number of electroporation protoplasts $\left(3 \times 10^{5}\right)$.

${ }^{* 3}$ Plus and minus signs indicate whether the nurse cells was present or absent in the culture. 
However, a clear correlation between $\mathrm{MgCl}_{2}$ concentrations and frequencies of the GUS positive cells have been observed.

In all the combinations of voltage and electric capacity the number of GUS positive cells was increased by using nurse culture. In some cases neither GUS positive cells nor viable cells were observed when the nurse culture was not used(data not shown). The nurse culture with Millicell reported here proved to be efficient and did not require any preparation of feeder layer or beads culture, which usually need complicated tissue culture techniques.

\section{Selection and regeneration of stable transformants}

The optimun condition defined for the transient expression was used for the stable transformation. Cell division began 6-7 days after electroporation. Compared to non-electroporation protoplast culture of $B$. napus cv. Westar, the onset of cell division was delayed 2-3 days. After one week in culture hygromycin B or kanamycin were added at final concentrations of $5 \mu \mathrm{g} / \mathrm{m} l$ and 10 $\mu \mathrm{g} / \mathrm{m} l$, respectively. Cell cultures consisting of $8-12$ cells were transferred to agarose solidified medium after 3 weeks in culture. Green calli proliferated on the selection medium(Fig. 1-b). When the calli reached $2-3 \mathrm{~mm}$ in diameter, they were transferred to DN medium to induce shoots. In our preliminary experiments, no colony formation was observed in the medium with kanamycin at $50 \mu \mathrm{g} / \mathrm{m} l$ or hygromycin $\mathrm{B}$ at $20 \mu \mathrm{g} / \mathrm{ml}$. To induce shoot formation the green calli on the selection medium were transferred to a series of media, K3, B5 and MS, every 3 weeks. In most cases shoot formation was induced on B5 medium(Fig. 1-c). The calli that did not form shoots on these media were further transferred to MS medium to induce shoots. Kanamycin or hygromycin $B$ resistant calli at transformation frequencies were $2.3 \times 10^{-4}$ and $4.1 \times 10^{-5}$, respectively. In total we obtained 5 and 6 regenerated plants from 140 kanamycin and 33 hygromycin resistant calli, respectively (Table 2). They were grown in Magenta box(Fig.1-d) and some on them were transplanted to soil. Three plants out of 6 hygromycin resistant plants produced self-pollinated seeds (Fig. 1-e, f). It is of interest to compare our results with those of Bergman and Glimelius though the transient transformation frequencies were comparable to our results, the stable transformation frequencies were 10 to 100 times lower than those of ours, suggesting that the observed high frequencies of stable transformation were caused by use of the nurse culture. In our experiments, the electroporated protoplasts were cultured with the tobacco nurse cells during the first week in culture, for the period the protoplasts start first cell division. This fact suggests that induction of high frequency first cell division of electroporated protoplasts by the nurse culture lead to high frequency of stable transformation.

\section{Molecular analysis of regenerated plants}

Molecular analysis for the presence of the transforming gene was carried out. All the regenerated plants were shown to be transformants by PCR(data not shown). Southern blot filter was probed with a full length of the $h p h$ gene(Fig. 2). All the plants carried an expected $0.97 \mathrm{~kb}$ EcoRI-Bam HI fragment. In the H-1 plant one band was seen and the intensity of the band correspond to approximately 1 copy/genome. However, $\mathrm{H}-2$ and $\mathrm{H}-3$ plants generated a number of copies, most of which were larger than expected. The additional bands which might indicate a rearrangement of the transgene and/or integration of multiple copies. To investigate co-transformation efficiency the GUS activity was measured. In the transformants one plant $(\mathrm{H}-3)$ showed GUS activity and the others did not. Thus the co-transformation efficiency was $33 \%$.

In some transgenic plants, like $\mathrm{H}-2$ and $\mathrm{H}-3$ plants in our experiments, high copy number of genes were introduced by electroporation, which suggests that complex patterns of segregation could be expected in the following generations. Complex segregation of marker genes and a target gene 
Table 2. Frequency of stable tansformation of electroporated protoplast.

\begin{tabular}{ccccc}
\hline Marker gene & $\begin{array}{c}\text { No. of treated } \\
\text { protoplasts }\left(\times 10^{5}\right)\end{array}$ & $\begin{array}{c}\text { No. of resistant } \\
\text { calli*1 }\end{array}$ & $\begin{array}{c}\text { No. of regenerated } \\
\text { plants }\end{array}$ & $\begin{array}{c}\text { Stable transformation } \\
\text { frequency }\end{array}$ \\
\hline npt II & 6 & 140 & 5 & $2.3 \times 10^{-4}$ \\
hph & 8 & 33 & 6 & $4.1 \times 10^{-5}$ \\
\hline
\end{tabular}

${ }^{* 1}$ Number of green calli proliferating on B5 medium with kanamycin at $10 \mu \mathrm{g} / \mathrm{m} l$ or hygromycin B at $5 \mu \mathrm{g} /$ $\mathrm{m} l$.

*2 Stable transformation frequency was calculated as the number of resistant calli divided by the number of electroporated protoplasts.

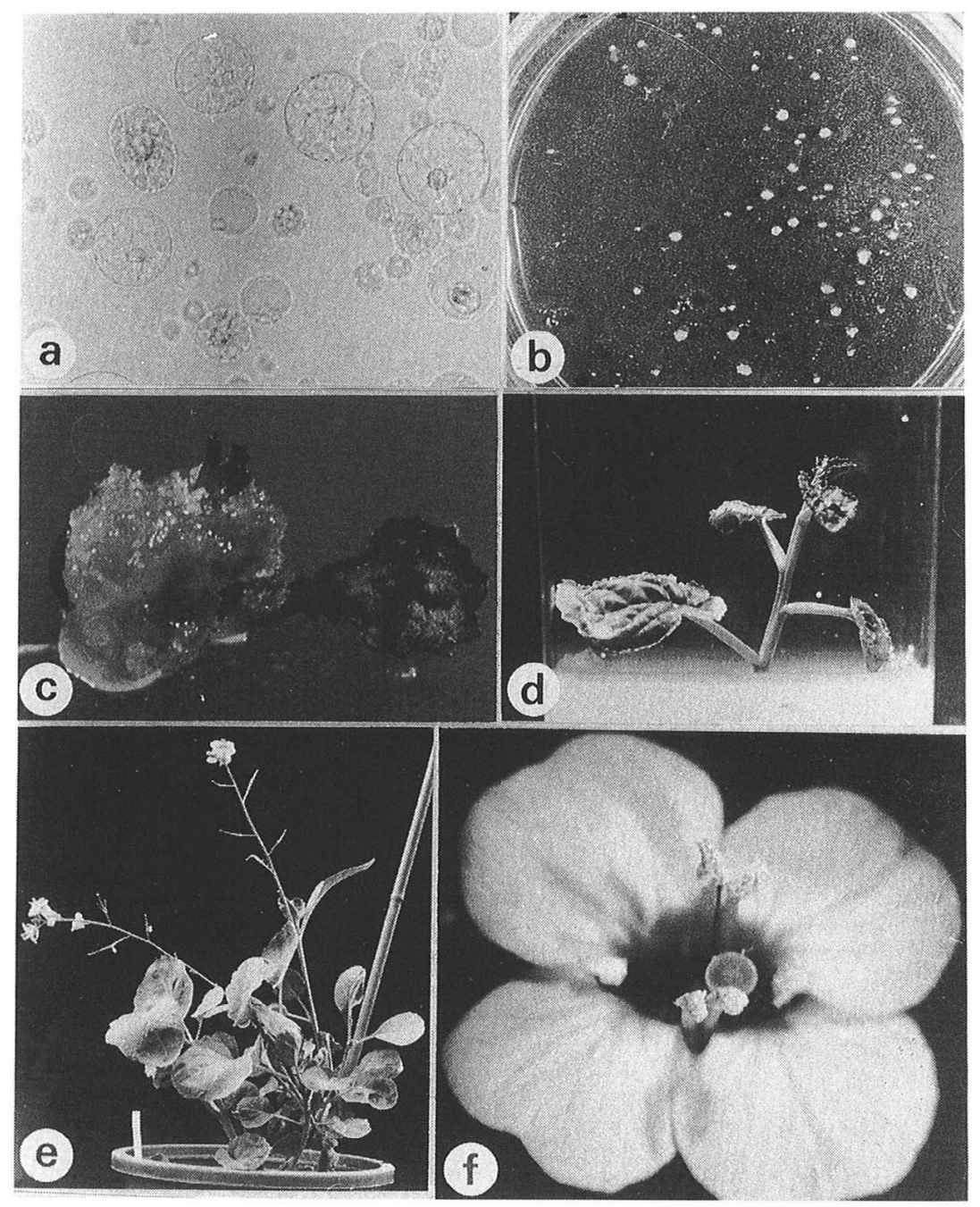

Fig. 1 Stable transformation of B. napus cv. Westar by electroporation.

Microscopic observation of the hypocotyl protoplasts prior to electropolation(a). Green calli proliferated on $\mathrm{CN}$ medium containing hygromycin B at $5 \mu \mathrm{g} / \mathrm{m} l 6$ weeks after electroporation(b). Regenerated green shoot on B5 medium containing $5 \mu \mathrm{g} / \mathrm{m} l$ of hygromycin B. The resistant shoot was observed 12 weeks after eletropolation(c). To induce root regenerated plants were transferred to MS medium containing $3 \%$ sucrose, $0.1 \mathrm{mg} / l \mathrm{NAA}, 0.01 \mathrm{mg} / l$ BAP 15 weeks after eletroporation(d). The transformant was fertile and set self-pollinated seeds(e). The flower of the transgenic plant showed normal appearance (f). 


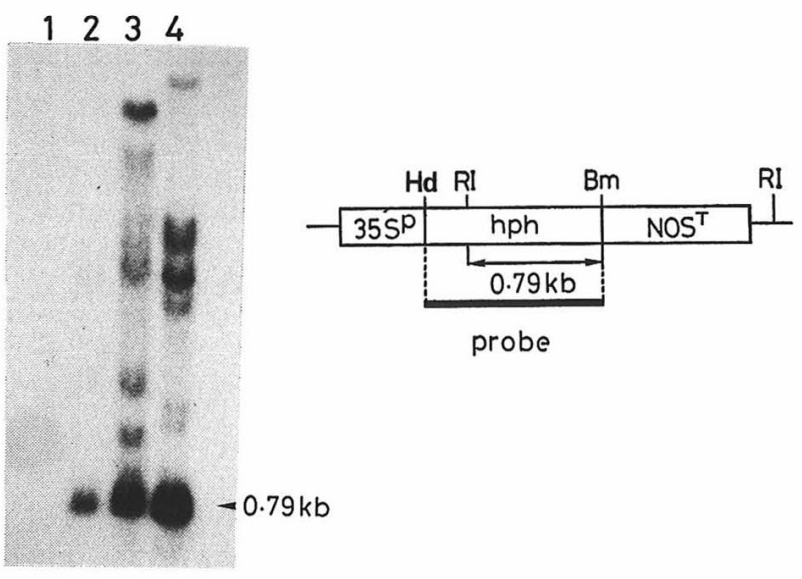

\section{EcoRI-BamHI digestion}

Fig. 2 Southern analysis for hph gene in transgenic rapeseed plants.

EcoRI-Bam HI digested DNA was probed with the ${ }^{32} \mathrm{P}-$ labeled HindIII-Bam HI digested fragment of pLAN101MHyg. Lane 1: B. napus cv. Westar, Lane 2-4: three independent hygromycin resistant plants, $\mathrm{H}-1, \mathrm{H}-2$ and $\mathrm{H}-3$, respectively. The $0.79 \mathrm{~kb}$ band was full length of the hph gene. Hd: HindIII, RI: EcoRI, Bm: BamHI, hph: hygromycin phosphotransferase gene, $\operatorname{NOS}^{\mathrm{T}}$ : nopaline synthase terminator, $35 \mathrm{~S}^{\mathrm{P}}$ : CaMV 35S promoter.

was reported in transgenic $B$. napus produced by electroporation ${ }^{6}$. In our small scale experiments, no segregation of the GUS and $h p h$ gene was observed in the self-pollinated progeny. To obtain transgenic plants lacking the marker gene, it will be required to find conditions to minimize the number of marker gene introduced by electroporation.

\section{References}

1) Thompson, K. F., W. G. Hughes, 1986. In "Oilseed rape" (eds. by Scarisbrich, D. H., R. W. Daniels), p. 32 82, Collins, London.

2) Miki, B. L., H. Labbé, T. Oellet, J. Gabard, G. Sunohara, P. J. Charest, V. N. lyer, 1990. Theor. Appl. Genet., 80: 449-458.

3) Knutzon, D. S., G. A. Thompson, S. E. Radke, W. B. Johnson, V. C. Knauf, J. C. Kridl, 1992. Proc. Natl. Acad. Sci. USA, 89: 2624-2628.

4) Altenbach, S. B., C. C. Kuo, L. C. Staraci, K. W. Pearson, C. Wainwright, A. Georgescu, J. Townsend, 1992. Plant Mol. Biol., 18: 235-245.

5) Dale, E. C., D. W. Ow, 1991. Proc. Natl. Acad. Sci. USA, 88: 10558-10562.

6) Hervé, C., D. Rouan, P. Guerche, M. H. Montancé, P. Yot, 1993. Plant Sci., 91: 181-193.

7) Gruerche, P., M. Charbonnier, L. Jouanin, C. Tourneur, J. Paszkowski, G. Pelletier, 1987. Plant Sci., 52: 111-116.

8) Bergman, P., K. Glimelius, 1993. Physiol. Plantarum, 88: 604-611.

9) Murashige, T., F. Skoog, 1962. Physiol. Plantarum, 15: 473-497.

10) Sakai, T., J. Imamura, 1990. Theo. Appl. Genet., 89: 421-427.

11) Fromm, M., L. P. Taylor, V. Wolbot, 1986. Nature, 319: 791-793.

12) Gritz, L., J. Davies, 1983. Gene, 25: 179-188.

13) Shimamoto, K., R. Terada, T. Izawa, H. Fujimoto, 1989. Nature, 337: 274-276.

14) Jefferson, R. A., 1987. Plant Mol. Biol. Rep., 5: 387-405.

15) Doyle, J. J., J. L. Doyle, L. H. B. Hortorium, 1990. Focus, 12: 13-15. 
16) Tada, Y., M. Sakamoto, T. Fujimura, 1990. Theor. Appl. Genet., 80: 475-480.

\title{
《和文要約》
}

エレクトロポーレーションによる形質転換ナタネの作出：

保護培養の形質転換効率への効果

\author{
村瀬淳子・湯 玲子・今村 順
}

\section{植物工学研究所}

ナタネ下胚軸由来プロトプラストにエレクトロポーレーションでGUS 遺伝子を導入し，そのトランジェ ントアッセイにより形質転換の電気条件及び培養条件を検討した。最適電気条件は, 電気容量 $400 \mu \mathrm{F}$, 電 圧 $600 \mathrm{~V} / \mathrm{cm}$, パルス幅 $7.5 \mathrm{msec}$. だった。 また, エレクトロポーレーション直後から, タバコ培養細胞を 用いて保護培養することにより，カルス形成率が増大した．これらの条件を用いて，カナマイシン及び八イ グロマイシン耐性植物を効率良く作出することができた。 